\title{
Énekesmadarak őszi vonulása csatornaparti fasoron
}

\author{
Bozó László ${ }^{1}$, Bozóné Borbáth Erna ${ }^{1}$ és Tar Levente ${ }^{2}$ \\ 15744 Kevermes, Battonyai utca 10. \\ 25600 Békéscsaba, Zsiros u. 10. fsz. 5. \\ e-mail: bozolaszlo91@gmail.com
}

\begin{abstract}
Összefoglaló: Csatornaparti spontán kialakult fasoron a madárgyürüzés eszközeit felhasználva végeztünk kutatást 2016 őszén, Kevermesen. Az általunk kiválasztott csatorna mellett referenciaként egy ezüstfásban is gyürüztünk és összehasonlítottuk a két területegységet abból a szempontból, hogy az egyes madárfajok melyik élőhelyet használják. A kutatás során kiderült, hogy a csatorna kulcsfontosságú a legtöbb átvonuló énekesmadárfaj számára, azonban a hosszabb ideig itt tartózkodó fajok egyedei már a táplálékban gazdagabb erdőben voltak jelen nagyobb számban. Több olyan faj is szorosan kötődik az őszi időszakban a csatornákhoz, amelyek egyébként erdőkben költenek. Mindezek miatt természetvédelmi szempontból indokolt lenne ezen élőhelyek védelme, vagy legalábbis a jelenlegi mértéktelen növényirtás visszaszorítása.
\end{abstract}

Kulcsszavak: énekesmadár vonulás, vízelvezető csatorna, fasor, madárgyürüzés, élőhelypusztulás

\section{Bevezetés}

A honfoglaláskori Magyarország erdősültsége 27\% körül lehetett, a 19. század végén mindössze $13 \%$ volt (Vahid \& Vahidné 2005), míg napjainkban kb. 25\% (http2). Az Alföld hazánk legkevésbé erdősült területe, ezen belül is a középső, valamint délkeleti része a fában legszegényebb terület, melynek erdősültsége messze alatta marad az országos átlagértéknek. Ráadásul ezen erdők is jellemzően kultúrerdők (Bartha 2012), legfőképpen nyarasok és akácosok. A XX. század kezdetére a hosszan tartó aszályos időszak okozta mezőgazdasági gondok és a trianoni békekötés miatt bekövetkezett erdőveszteség és fahiány miatt elötérbe került az Alföld fásításának gondolata. Bár korábban is történtek próbálkozások, illetve kifejezetten erre vonatkozó jogszabály is született (1923. évi XIX. törvénycikk az alföldi erdő telepítéséról és a fásításokról, Anonim 1), a nagyszabású telepítések az 1950-es évektől indultak (Rakonczay 1992). A fásítások erdők, valamint jelentős részben fasorok, erdősávok telepítését jelentették, melynek keretében az Alföldön 273 ezer ha erdőt és 1500 km hosszan elnyúló mezővédő erdősávot telepítettek (Szarvas 2010). A fásítási folyamat azonban csak az 1960-as évek kezdetéig 
tartott, amikor a korszerü agrotechnikák alkalmazása, a nagyobb mezőgazdasági táblák kialakítása, majd később a légi növényvédelem elterjedése miatt megállt.

A mezővédő fasorok, erdősávok telepítése jellemzően gazdasági érdekek miatt történt. A 18. században a futóhomok megkötése volt a cél, míg a 20. században a szél erejének csökkentésével a talaj és a termesztett növény védelmére használták.

Természetvédelmi jelentőségükkel korábban nem foglalkoztak, csak néhány publikációban vizsgálták azt (pl. Gál 1968). Az évek során azonban bebizonyosodott, hogy a fátlan alföldi tájakon kiemelt jelentőséggel bírnak még az egyébként értéktelennek tünő, egymásba kapcsolódó facsoportok, sövények és erdősávok is (Legány 1991, Halász et al. 2015), akárcsak Európa más részein is (Wretenberg et al. 2010, Princé \& Jiguet 2013). Bár legtöbbjük 15-20 éven beül kivágásra kerül, azonban az élővilág bizonyos csoportjai, például a madarak gyors alkalmazkodásra képesek, így ezt az élőhelypusztulást képesek túlélni más élőhelyre való költözéssel. Egy Debrecen melletti területen például megfigyelték, hogy egy fasor kivágását követő évben egy ahhoz közeli fasoron kb. 20\%-al több madár lett, mint az előző évben, tehát feltehetően oda költöztek át (Szarvas 2010). A fasorok mind fészkelö, mind táplálkozóhelyként funkcionálnak, így a madarak az év minden részében használják azokat (Herrmann \& Plakolm 1991, Kromp 1998). Ugyanakkor Legány (1991) kimutatta, hogy a madarak elsősorban nem itt, hanem a környező mezőgazdasági területeken szerzik be táplálékukat. A kisebb fajgazdagságú mezőgazdasági területeken a fasorok így betölthetik az ökológiai- vagy zöldfolyosó szerepet is (Takács 2008).

A mezővédő fasorokhoz hasonló jelentőséggel bírnak a belvízelvezető és öntözőcsatornák is, mint egyfajta vonalas létesítmények változó csatornaparti növényzettel. Egy részük jellemzően időszakos vízállású, ősztől tavaszig vízzel borítottak, míg nyárra kiszáradnak. A víz mennyisége alapvetően meghatározza növényzetüket is, mivel száraz területeken emberi beavatkozás hiányában akár füzesek, kökényesek is kialakulhatnak partjuk mentén. Dolgozatunk mintavételi területeit is csatornapartokon spontán kialakult fasorok képezték. Vizsgálatunkban arra a kérdésre kerestük a választ, hogy ezek a kombinált élőhelyek (mezővédő fasor - vízelvezető csatorna) pontosan milyen szerepet játszanak a madárvonulás során. A mezővédő fasorok nyári madárvilágával több tanulmány is foglalkozott (Gál 1968, Herrmann \& Plakolm 1991, Legány 1991, Kromp 1998, Szarvas 2010), amelyek részben érintették a fasorok vonulásban betöltött szerepét is. Szarvas (2010) költési időszakban történt megfigyelései szerint többnyire közönséges, széleskörben elterjedt énekesmadarak fordultak elő a fasorokban, míg Legány (1991) arra világított rá, hogy elsősorban azok a fajok képesek itt megmaradni, amelyek képesek elviselni a zavarást és a fasorok nyújtotta szegényes viszonyokat. Természetesen a madárfajok száma a fasor kiterjedésétől, korától, a 
növényzet változatosságától, az esetlegesen a fasor mellett húzódó utak forgalmától és az alkalmazott mezőgazdasági technológióktól (vegyszerek, munkagépek a fasort körülvevő szántókon) is nagymértékben függ (Legány 1991, Gál \& Marosán 2003, Szarvas 2010).

A tanulmányban a napjainkban égető problémaként jelentkező, csatornákat érintő élőhelypusztításra szeretnénk rávilágítani.

\section{Módszerek}

Kutatásunkat Békés megye délkeleti részén, Kevermes település közigazgatási határán belül az egykori fácántelep területén végeztük (EOV 815638 123876), amely egy 7 hektár kiterjedésü ezüstfás (Elaeagnus angustifolia). A kutatóhely ennek az erdőnek az északi részén került kialakításra egy kb. 0,5 hektáros foltban (1. ábra). Alapvetően bokros élőhelyről van szó függetlenül attól, hogy több magas fa is fellelhető a területen. Az erdő átlagos magassága 3,5-4 méter, a domináns ezüstfa mellett néhány ennél magasabb szil (Ulmus sp.), akác (Robinia pseudoacacia) és vadkörte (Pyrus pyraster) is megtalálható itt elegyben. A cserjeszintet fekete bodza (Sambucus nigra) és kökény (Prunus spinosa) alkotja, míg az alsóbb szinteken gyakori a hamvas szeder (Rubus caesius). Az erdőszélen sürübb

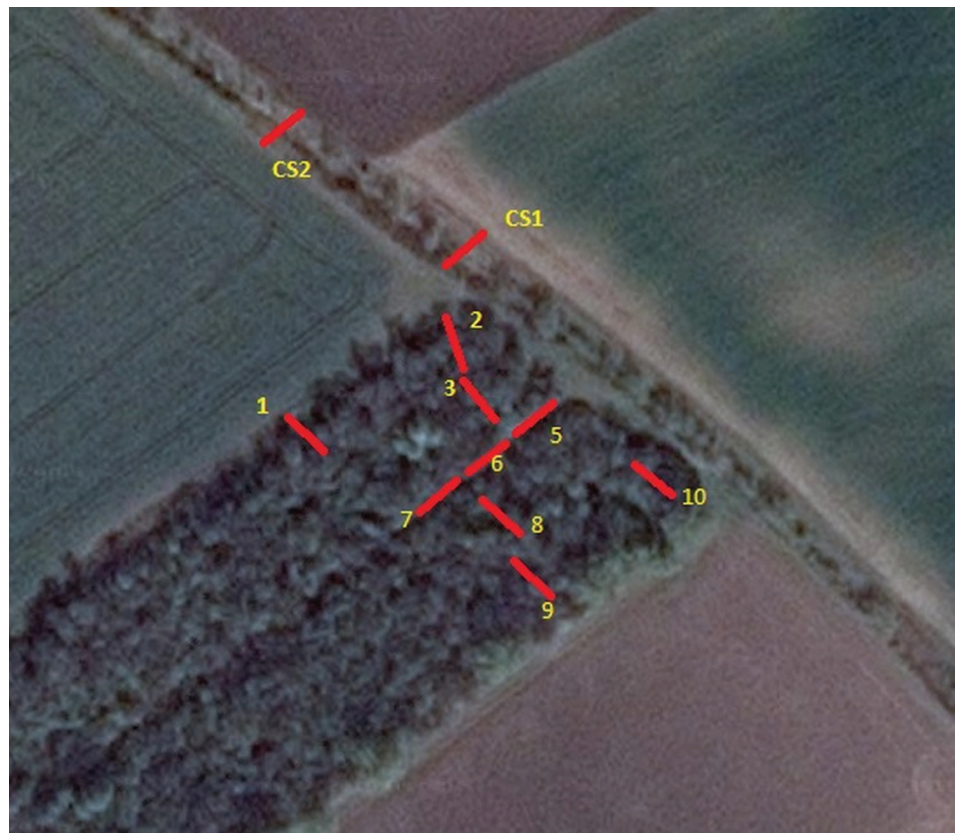

1. ábra. A hálók elhelyezkedése a kutatási területen (http1). 
a növényzet, itt nádas és gyomos foltok is vannak. Közvetlenül az erdő mögött egy DK - ÉNY lefutású vízelvezető csatorna húzódik, amelynek partján kosárfonó füzek (Salix viminalis), fiatal diófák és nyárfák álltak, míg a parton és a mederben sürü nádas volt. A csatorna sekély medrü, víz csak a mélyebb részeken állt benne, az is csak nagyrészt október második felétől kezdődően.

Munkánk során a madárgyürüzés módszerét használtuk, amelynek során japán típusú függönyhálókkal fogtuk meg a madarakat, majd a fém jelölőgyürük felhelyezését követően különböző biometriai adatokat (szárnyhossz, testzsír, tömeg) vettünk fel róluk, meghatároztuk korukat és ivarukat, végül elengedtük őket. Öszszesen 11 háló volt kihelyezve, melyek egy kivételével 5 zsebesek, 12 méter hoszszúságúak és 16 mm szembőségüek voltak. Az egyetlen kivétel a CS2 háló volt, amelyre a csatorna vízfelszíne felett és az alacsonyabb növényzetben mozgó fajok megfogása céljából 2 zseb lett pluszba felvarrva, így ez 7 zsebes és 12 méteres volt. A 11 háló közül 9 az ezüstfásban állt, míg 2 a csatornában lett felállítva.

A munka 2016. augusztus 8. és október 27. között zajlott, ami nagyjából magában foglalja a teljes vonulási periódust mind a nádi, mind a cserjeszintben élő fajoknál. Arra törekedtünk, hogy heti két teljes napot gyürüzzünk és ez a 12 hétből 10 héten így is volt. A szeptember 19. és 25. közötti héten az eső miatt csak egy napot tudtunk gyürüzni, míg a következő héten 3 napig voltak széthúzva a hálók. Egy nap 8 órát, azaz 8 ellenőrzést jelentett, összességében tehát mintegy 192 órát gyürüztünk. A hálókat minden alkalommal késő délután, a meleg enyhülése után húztuk szét, az utolsó ellenőrzésre naplemente után fél órával került sor. Estére széthúzva maradtak, míg a reggeli első ellenőrzés napkelte után fél órával történt meg. Délelőtt a hőmérséklettől függően, de legkésőbb 11 óráig folyt a munka, majd összehúztuk a hálókat.

Dolgozatunkban az ezüstfásban álló 9 háló referenciaként szolgált annak érdekében, hogy megvizsgáljuk, az összefüggő, táplálékban gazdag erdő vagy a csatorna játszik-e fontosabb szerepet a madarak vonulásában. Az elemzés során vonulónak tekintettük azokat a fajokat, amelyek a vizsgálati periódus során átvonultak a területen (tehát pl. a fekete rigó (Turdus merula), az erdei pinty (Fringilla coelebs), a tengelic (Carduelis carduelis) stb. is ide tartozik), míg állandó akkor volt egy faj, ha csak ugyanazok a példányok mozogtak a területen a teljes időszakban. Az adatfeldolgozáshoz egytényezős varianciaanalízist végeztünk a Microsoft Excel 2016 program segítségével, majd a post hoc test-ként Tukey HSD Testet végeztünk melyhez a www.vassarstats.net online rendszert használtuk (http3). Ez utóbbi azonban csak maximum 5 csoport összehasonlítására alkalmas, így az egymás melletti, illetve azonos élöhelyen levő hálókat, páronkénti összehasonlítás után (egytényezős varianciaanalízis a Microsoft Excel 2016 programmal), ha nem adott szignifikáns eltérést, átlagolva összevontuk a tört számokat egészre 
1. táblázat. Az egyes hálókkal fogott madarak mennyisége. A táblázat fejlécében szereplő számok és betük a hálók elnevezését adják meg.

\begin{tabular}{|c|c|c|c|c|c|c|c|c|c|c|c|}
\hline Faj & $\mathrm{CS} 1$ & $\mathrm{CS} 2$ & 1 & 2 & 3 & 5 & 6 & 7 & 8 & 9 & 10 \\
\hline Vörösbegy Erithacus rubecula & 20 & 51 & 21 & 9 & 9 & 6 & 9 & 8 & 9 & 8 & 16 \\
\hline Fekete rigó Turdus merula & 2 & 34 & 7 & 6 & 7 & 3 & 7 & 8 & 19 & 17 & 12 \\
\hline Csilpcsalpfüzike Phylloscopus collybita & 31 & 35 & 10 & 5 & 1 & 2 & 1 & 0 & 1 & 5 & 18 \\
\hline Barátposzáta Sylvia atricapilla & 27 & 28 & 7 & 4 & 0 & 1 & 1 & 1 & 8 & 8 & 12 \\
\hline Kék cinege Cyanistes caeruleus & 23 & 30 & 13 & 1 & 2 & 10 & 0 & 0 & 0 & 3 & 5 \\
\hline Fitiszfüzike Phylloscopus trochilus & 23 & 25 & 7 & 2 & 1 & 1 & 0 & 0 & 1 & 0 & 1 \\
\hline Öszapó Aegithalos caudatus & 10 & 8 & 0 & 1 & 0 & 9 & 0 & 0 & 2 & 3 & 6 \\
\hline Kerti geze Hippolais icterina & 17 & 8 & 6 & 2 & 0 & 0 & 0 & 0 & 0 & 0 & 0 \\
\hline Széncinege Parus major & 6 & 12 & 0 & 0 & 1 & 2 & 0 & 0 & 2 & 5 & 2 \\
\hline Énekes rigó Turdus philomelos & 0 & 8 & 0 & 3 & 0 & 1 & 1 & 2 & 1 & 6 & 8 \\
\hline $\begin{array}{l}\text { Foltos nádiposzáta } \\
\text { Acrocpehalus schoenobaenus }\end{array}$ & 28 & 0 & 0 & 0 & 0 & 0 & 0 & 0 & 0 & 0 & 0 \\
\hline Kis poszáta Sylvia curruca & 7 & 11 & 1 & 3 & 0 & 3 & 0 & 0 & 1 & 1 & 1 \\
\hline Erdei pinty Fringilla coelebs & 3 & 6 & 0 & 2 & 2 & 7 & 1 & 0 & 1 & 2 & 0 \\
\hline Mezei poszáta Sylvia communis & 7 & 5 & 8 & 3 & 0 & 0 & 0 & 0 & 0 & 0 & 0 \\
\hline Mezei veréb Passer montanus & 7 & 14 & 0 & 0 & 0 & 0 & 0 & 0 & 0 & 0 & 0 \\
\hline Énekes nádiposzáta Acrocephalus palustris & 13 & 2 & 4 & 0 & 0 & 0 & 0 & 0 & 0 & 0 & 0 \\
\hline Ökörszem Troglodytes troglodytes & 3 & 6 & 3 & 3 & 0 & 2 & 0 & 1 & 0 & 0 & 0 \\
\hline Fülemüle Luscinia megarhynchos & 1 & 0 & 7 & 2 & 1 & 0 & 1 & 0 & 1 & 2 & 0 \\
\hline Kerti rozsdafarkú Phoenicurus phoenicurus & 1 & 3 & 1 & 0 & 0 & 1 & 0 & 0 & 1 & 0 & 1 \\
\hline Sisegő füzike Phylloscopus sibilatrix & 1 & 2 & 0 & 0 & 1 & 0 & 0 & 0 & 0 & 3 & 0 \\
\hline Tengelic Carduelis carduelis & 6 & 0 & 1 & 0 & 0 & 0 & 0 & 0 & 0 & 0 & 0 \\
\hline Tövisszúró gébics Lanius collurio & 2 & 4 & 0 & 0 & 0 & 0 & 0 & 0 & 0 & 0 & 0 \\
\hline Nagy fülemüle Luscinia luscinia & 1 & 1 & 1 & 0 & 2 & 0 & 0 & 0 & 0 & 0 & 0 \\
\hline Kerti poszáta Sylvia borin & 2 & 1 & 1 & 1 & 0 & 0 & 0 & 0 & 0 & 0 & 0 \\
\hline Sárgafejü királyka Regulus regulus & 1 & 1 & 0 & 0 & 0 & 1 & 1 & 0 & 0 & 1 & 0 \\
\hline Nádirigó Acrocephalus arundinaceus & 4 & 0 & 0 & 0 & 0 & 0 & 0 & 0 & 0 & 0 & 0 \\
\hline Erdei szürkebegy Prunella modularis & 2 & 0 & 1 & 1 & 0 & 0 & 0 & 0 & 0 & 0 & 0 \\
\hline $\begin{array}{l}\text { Cserregő nádiposzáta } \\
\text { Acrocephalus scirpaceus }\end{array}$ & 2 & 2 & 0 & 0 & 0 & 0 & 0 & 0 & 0 & 0 & 0 \\
\hline Szürke légykapó Muscicapa striata & 0 & 0 & 0 & 0 & 1 & 0 & 0 & 0 & 0 & 1 & 0 \\
\hline Süvöltő Pyrrhula pyrrhula & 0 & 0 & 0 & 1 & 0 & 0 & 0 & 0 & 0 & 0 & 0 \\
\hline Tüzesfejü királyka Regulus ignicapilla & 0 & 0 & 0 & 0 & 0 & 1 & 0 & 0 & 0 & 0 & 0 \\
\hline Berki tücsökmadár Locustella fluviatilis & 0 & 0 & 1 & 0 & 0 & 0 & 0 & 0 & 0 & 0 & 0 \\
\hline Zöld küllő Picus viridis & 0 & 0 & 0 & 0 & 0 & 0 & 0 & 0 & 1 & 0 & 0 \\
\hline Cigánycsuk Saxicola torquata & 1 & 0 & 0 & 0 & 0 & 0 & 0 & 0 & 0 & 0 & 0 \\
\hline Nyaktekercs Jynx torquilla & 0 & 0 & 1 & 0 & 0 & 0 & 0 & 0 & 0 & 0 & 0 \\
\hline
\end{tabular}


kerekítve. A nullhipotézis az volt, hogy nincs különbség az egyes mikrohabitatok fajkészletében.

\section{Eredmények}

A tárgyalt időszakban 35 faj 838 egyedére került gyürü, továbbá 173 visszafogásunk is volt (1. táblázat).

Általánosságban elmondható, hogy a bokrosban és nádasban élő fajok egyaránt nagy számban kerültek kézre.

Az 2. ábra azt mutatja be, hogy az egymást követő hetekben átlagosan hány egyed került kézre naponta (az egyes heteken belüli gyürüzések adatait átlagoltuk

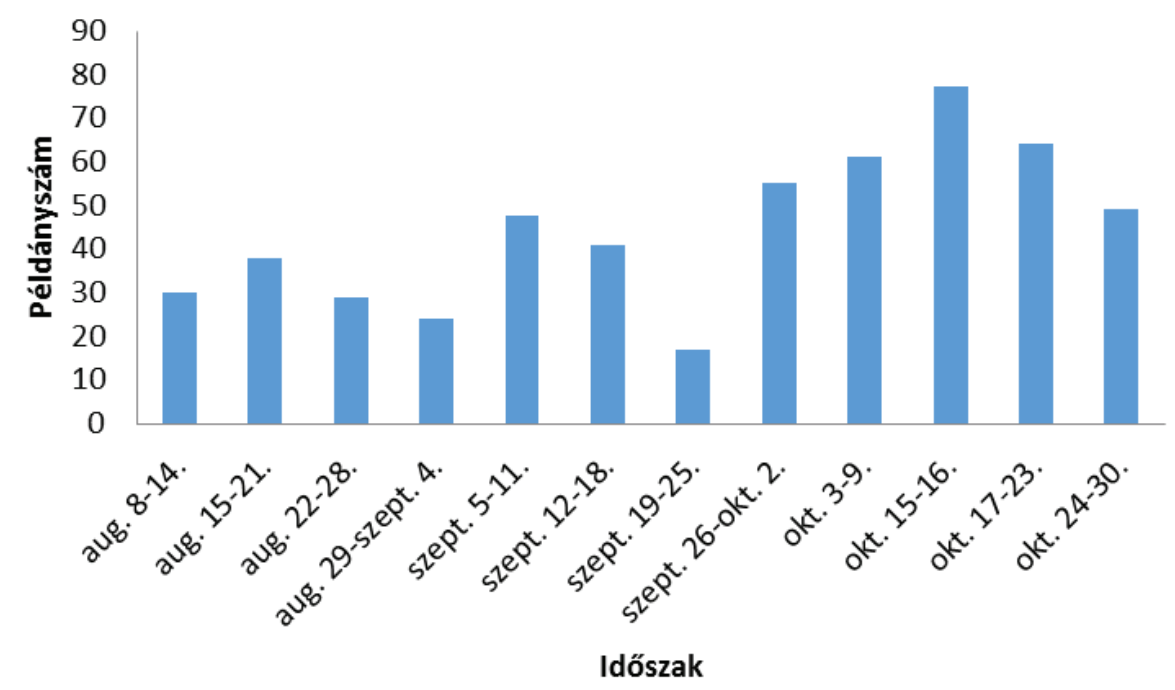

2. ábra. A fogott madarak példányszámának átlaga heti bontásban.

annak érdekében, hogy a szeptember 19. és 25., ill. a szeptember 26. és október 2. közötti időszakok kevésbé legyenek kiugróak). Az ábrán látható, hogy augusztus végén van egy törés, ami a nádi madarak eltünésével esik egybe, ezt követően szeptember 2. hetében kezdett el ismét növekedni a madarak mennyisége, köszönhetően nagyrészt a vörösbegyeknek, kék cinegéknek (Parus caeruleus) és csilpcsalpfüzikéknek.

Az egyes hálók fogási eredményeit az 1. táblázat, valamint a 3. ábra mutatja be. Eszerint a csatornában álló két háló több madarat fogott (548), mint a többi 


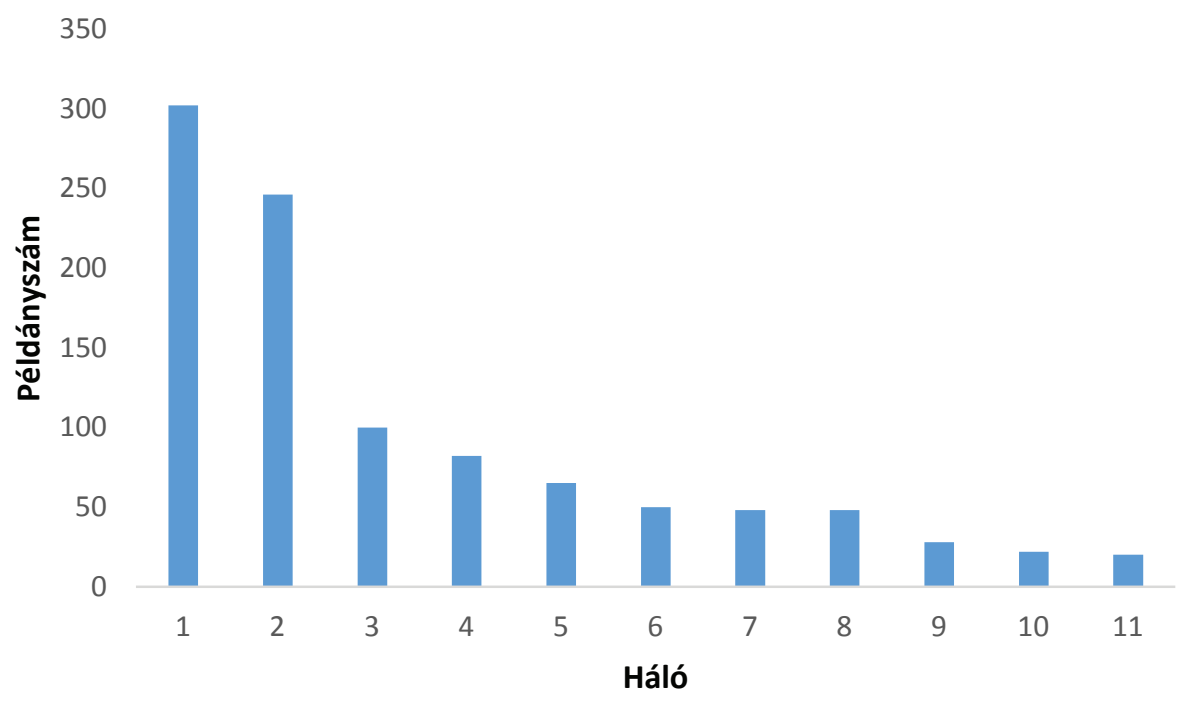

3. ábra. Az egyes hálókban fogott madarak példányszáma.

kilenc együttesen (463). Továbbá az is látszik, hogy a legkevesebb madár a belső hálókban akadt meg, jelezve, hogy vonuláskor előnyben részesítik az erdőszéleket. Ezt mi sem bizonyítja jobban, mint hogy az 1-es háló fogta az erdős hálók közül a legtöbbet. Érdekes, hogy a CS2 annak ellenére kiemelkedően a legtöbbet fogta, hogy csak augusztus végén lett kihelyezve. A statisztikai elemzés szerint a csatornában levő hálók között nincs szignifikáns fajkészletbeli különbség $(\mathrm{p}=0,63)$, valamint az ezüstfásban sincs szignifikáns különbség az egyes hálók között (minden esetben $\mathrm{p}>0,05$ ). A csatornabeli hálók és az ezüstfásban levő hálók között azonban szignifikáns különbség mutatkozik (minden esetben $\mathrm{p}<0,01$ ).

A 29 vonuló faj 58,6\%-a esetében a csatorna hálókban akadt meg a legtöbb egyed. A fennmaradó 12 fajból 6 csupán 1 vagy 2 alkalommal lett megfogva, tehát csak 6 olyan faj volt, amely rendszeres vendég volt a területen és elsősorban nem a csatornában mozgott (énekes rigó (Turdus philomelos), fülemüle (Luscinia megarhynchos), sisegö füzike (Phylloscopus sibilatrix), nagy fülemüle (Luscinia luscinia), sárgafejü királyka (Regulus regulus). A nádiposzáták 92,7\%-a szintén a csatornában lett megfogva, míg a bokorposzáták (kerti poszáta (Sylvia borin), barátposzáta (Sylvia atricapilla), kis poszáta (Sylvia curruca), mezei poszáta (Syvia communis) esetén 57,5\% ez a szám. A füzikék is hasonlóképpen oszlottak el a két területrész között (66,1\% a csatornában). Nagyon fontos kiemelni, hogy összességében az 1-es háló is kiemelt eredménnyel zárt, míg az erdő belsejében 
csak néhány faj (például a két fülemüle-faj vagy a fekete rigó) produkált nagyobb számokat.

\section{Értékelés}

A fasorok, erdősávok és vízelvezető árkok egyes fátlan tájakon kiemelt szerepet töltenek be úgy gazdasági, mint ökológiai szempontból. Alapvetően azért ültették/ ültetik őket, hogy a szél sebességének csökkentésével mérsékeljék a talajeróziót, illetve annak szárító hatását (Marton \& Csikós 2004). Emellett hatással vannak a hőmérsékletre, a talaj- és levegő nedvességére, a csapadékeloszlásra, a párolgásra, és ezeken keresztül a terméseredményre, sőt még az emberi egészségre is (Szavas 2010). Gyakorlati szempontból fasornak az 1 soros, míg erdősávnak a 2-3 sros, legfeljebb 20 méter széles fásítást nevezzük. Ami ennél nagyobb kiterjedésú, az már az erdő kategóriába tartozik. Az elsődleges rendeltetésen túl továbbiak is megadhatóak, ami célszerü is, hiszen ezeknek a fasoroknak és erdősávoknak komoly természetvédelmi és gazdasági szerepük is van (pl. különféle ökoszisztéma szolgáltatások). Az élővilág szerves részeit képező kis- és nagyvadak, így az Alföldön a fácán (Phasianus colchicus), a mezei nyúl (Lepus europaeus) vagy éppen az őz (Capreolus capreolus) számára is nélkülözhetetlen búvóhelyet biztosítanak. Ez már egy másik ágazat, a vadgazdálkodás érdekeibe tartozik, ugyanakkor egyes helyeken a fasorok és egyéb természetközeli élőhelyek hiánya jelentős belterületi kártételekhez vezet (Bozó L. személyes megfigyelése). Sok esetben zöld folyosóként működnek, ami hatványozottan igaz a vízelvezető csatornákra, hiszen azok hosszukat tekintve jelentősebb kiterjedésủek. A madarak közül számos faj fészkel fasorokon vagy erdősávokban, hazánkban sok fokozottan védett faj is, mint például a kék vércse (Falco vespertinus) és a parlagi sas (Aquila heliaca) (MME Nomenclator Bizottság 2008, Horváth 2009, Széles 2010). Ausztriai vizsgálatok alapján elsősorban kistestü énekesmadarak költenek ezeken az élőhelyeken (kenderike (Carduelis cannabina), fülemüle, mezei poszáta stb.), az őszi aratások idején pedig innen indulnak el az olykor több száz példányos pintycsapatok táplálkozni (Kromp 1998). Debrecen környéki fasorokon 52 madárfaj jelenlétét mutatták ki (Szarvas 2010). Az irodalomban található adatok mind távcsöves megfigyelésekre hivatkoznak, amely csak költési időben ad megbízható eredményeket. A fészkelő madarak számának becslésére gyakran a pontszámlálásos módszert alkalmazzák, melynek során adott UTM négyzeten belül 100 méter sugarú körökben jegyzik fel az észlelt madárfajok egyedszámát (pl. a Mindennapi Madarak Monitoringja is erre épül; Szép 2007). A vonuló fajok pontos detektálására ugyanakkor ez a módszer nem feltétlenül alkalmas, hiszen amíg költési időszakban énekelnek a 
madarak, addig (főként az őszi) vonulás során mindez már nem igaz. Éppen ezért a vonuló madarak észlelésére és monitorozására a madárgyürüzés a legalkalmasabb eszköz, hiszen az alkalmasan kiválasztott hálóhelyeken az adott élöhelyen átmenő legtöbb énekesmadárfaj megfogható, illetve pontosabban meghatározható az egyedek tényleges száma. Mindez természetesen csak azokra a fajokra vonatkozik, amelyekre az általunk kiválasztott hálótípus alkalmas, illetve az is nagyon fontos tényező lehet, hogy a hálót milyen magasságban használjuk. Sok faj (pl. füzikék) jellemzően a lombok között mozog, ezért ha ezeket a fajokat kívánjuk megfogni, akkor célszerú a lombkorona szintjére húzni a hálókat.

A vizsgálati időszak már egyetlen faj költési időszakába sem esett bele. Ezt jól bizonyítja, hogy fejlett kotlófoltú madarat egyáltalán nem fogtunk, illetve a vizsgálati területen fészkelő fajok egyedszáma (fekete rigó, barátposzáta, erdei pinty, énekes rigó (Turdus philomelos)) is csak szeptembertől kezdett emelkedni. Ennek pontos okát nem tudjuk, de talán az állhat a hátterében, hogy az ezüstfásban fészkelő madarak költési sikere az adott évben alacsony volt. Mivel elsősorban arra voltunk kíváncsiak, hogy a csatornaparti fás-bokros-nádas vegetáció milyen szerepet tölt be a különböző fajok vonulásában, a kökénnyel, szederrel, bodzával elegyes ezüstfásban álló hálókra referenciaként tekintettünk a vizsgálatban. Ennek okán a referenciaterületünk táplálékban gazdag, míg a csatorna ebből a szempontból kevésbé előnyös tulajdonságokkal rendelkezik.

A nádi énekesek (foltos nádiposzáta (Acrocephalus schoenobaenos), cserregö nádiposzáta (Acrocephalus scirpaceus), nádirigó (Acrocephalus arundinaceus)) kizárólagosan a csatornát használták vonulásuk során, az erdőbe egyáltalán nem mentek át. Ezek a fajok vonuláskor nem feltétlenül ragaszkodnak a nádasokhoz, bármilyen cserjés élőhelyen felbukkanhatnak (MME Nomenclator Bizottság 2008). Ebben az esetben viszont úgy tünik, hogy a csatorna elegendő táplálékot biztosított a számukra, nem volt szükséges elhagyni azt. Az énekes nádiposzáta (Acrocephalus palustris) - amely csatornapartokon, gyomos, náddal elegyes területeken fészkel (Haraszthy 1998) - már néhány esetben előkerült a referenciaterületen is, de csak az 1-es, szélső hálóban, tehát ez sem jutott be a zártabb erdőbe. Meglepő volt, hogy az énekes nádiposzáta jóval gyakrabban lett fogva, mint a cserregő nádiposzáta. Ennek hátterében véleményünk szerint az állhat, hogy a cserregő fészkelőhelyéből adódóan alapvetően ritkább a tájban és így vonuláskor sem érinti nagy számban a térséget. Az énekes nádiposzáta ezzel szemben közönséges fészkelő a térségben, és így nem kizárt, hogy ezeket a madarakat a csatorna úgy gyüjti össze vonuláskor, mint a nagy folyó a kisebbet, kiváló vonulási utat garantálva számukra.

Az ún. bokorposzáták nevükből adódóan elsősorban fás vegetációhoz kötődnek, de eredményeink rávilágítottak, hogy vonuláskor a csatorna fontosabb ezen 
fajok számára, mint az erdő. A barátposzáta esetén még azt lehet látni, hogy az erdő belsejét is használják, a kerti, mezei és kis poszátánál viszont már szinte csak a csatorna és az erdőszél játszik szerepet a vonulásban. Érdekes a kerti geze (Hippolais icterina) helyzete, amely a térségben egyáltalán nem költ (Bozó 2012, 2014, 2015), viszont országos szinten nézve is nagy mennyiségben fogtuk. A csatorna szerepe itt is megkérdőjelezhetetlen, a zárt erdőben egyáltalán nem fogtuk.

A vörösbegy fogási mintázata is említésre érdemes, mivel ennél a fajnál ha kevéssel is, de az erdőben több egyed akadt hálóba, mint a csatornában. Ez nem meglepö, hiszen erdei fajról beszélünk, ugyanakkor a vonulásban mégiscsak a csatorna tölti be a vezető szerepet. Ezt az jelzi, hogy a visszafogások nagyrészt az erdőben, míg az új fogások főként a csatornában történtek. Összegezve tehát a vörösbegy már megáll itt táplálkozni és azok a madarak az erdőt használják ebből a célból.

A fekete rigó a vörösbegyre emlékeztető mintázatot mutat, itt is egyértelmüen látszik az átvonulók és a helyben maradók területhasználata közötti különbség.

A fészkelőhelyül szolgáló erdőket télire nádasra váltó fajok, így a kék cinege és az ökörszem (Troglodytes troglodytes) számára is nélkülözhetetlen a csatorna, éppúgy, mint a tövisszúró gébicseknek (Lanius collurio).

A fülemülék és nagy fülemülék kivételt képeznek az eddig bemutatott fajoktól, ezek ugyanis a zárt erdőt és az erdőszéli bokrosokat részesítették előnyben. Azt gondoljuk, hogy ez azért van, mert ezek a fajok a talajon vagy ahhoz közel szerzik be táplálékukat és kedvelik a sürü növényzetet, így a csatorna nem feltétlenül alkalmas élőhely számukra.

Végül ellent kell mondani annak a feltételezésnek, miszerint a fasorokat és erdősávokat csak gyakori énekesmadárfajok használják. Költéskor természetesen csak azok a fajok tudnak ott megtelepedni, amelyeknek elegendő a néhány sor fából álló vegetáció, vonuláskor viszont egészen más a helyzet. A csatornában olyan, a tájban érdekes fajokat fogtunk ugyanis, mint a kerti rozsdafarkú, az erdei szürkebegy (Prunella modularis) vagy a sárgafejú királyka, míg a referencia erdősávban süvöltő (Pyrrhula pyrrhula), nyaktekercs (Jynx torquilla), berki tücsökmadár (Locustella fluviatilis) és tüzesfejủ királyka (Regulus ignicapilla) is hálóba akadt. Ez a változatos fajkészlet tovább erősíti ezen élőhelyek jelentőségét.

Összességében a madárgyürüzések eredményeképpen megállapítható, hogy a vizsgált vízelvezető csatorna és a partján húzódó fasor az őszi vonulás során a legtöbb énekesmadárfaj számára kulcsfontosságú, legyenek azok alapvetően nádasban vagy erdőben élő fajok. Az is megállapításra került, hogy azok a madarak, amelyek gyorsan, pihenő beiktatása nélkül vonulnak át a területen, vonulási folyosóként tekintenek a csatornára, ezt részesítik előnyben a nagyobb kiterjedésü, táplálékban gazdag erdővel szemben. Ugyanakkor azt is ki kell emelni, hogy a 
hosszabb távon a területen maradó fajok egyedei már inkább az erdőt választják, valószínủleg az elérhető táplálékforrás nagyobb mennyisége miatt.

Természetvédelmi szempontból rendkívül fontos tehát a csatornaparti fasorok védelme, hiszen a fátlan tájakon a madaraknak nincs más választása, csak ezeket tudják használni vonulásuk során. A napjainkban zajló mértéktelen csatornatakarítási program ezért rendkívül káros hatással van az élővilágra, így hosszú távon mindenféleképpen újra kell gondolni ezt a tevékenységet és csökkenteni kell a vele járó káros hatások mértékét. A csatornák mederterületének növényzetmentesítése természetesen fontos vízügyi feladat, de az általunk észlelt módszerek és hozzá nem értés miatt sokszor ez a munka kiterjed a csatorna medrétől távolabb eső területekre is. Sokszor több tíz éves bokrosokat és fasorokat tarolnak le, majd a levágott faanyagot a helyszínen hagyják, csak a vastagabb, fütésre alkalmas darabokat viszik el. Véleményünk szerint egy kontrollált, szakemberek által végzett munka során ezek a problémák kiküszöbölhetők lennének.

Köszönetnyilvánitás - A szerzők hálásak Nagy Pálnak, a terület tulajdonosának, illetve a Kevermesi Vadásztársaságnak, hogy a területet minden további nélkül rendelkezésükre bocsátották. A terepi munkában végzett segítségükért a szerzök köszönetüket fejezik ki Fekete Ágnesnek és Nagy Krisztiánnak. A gyürüzést a Magyar Madártani és Természetvédelmi Egyesület 2. sz. Békés Megyei Helyi Csoportja és a Dél-békési Természetvédelmi és Madártani Egyesület támogatta anyagilag.

\section{Irodalomjegyzék}

Anonim, 1 (1923): 1923. évi XIX. törvénycikk az alföldi erdő telepítéséről és a fásításokról.

Bartha, D. (2012): A magyarországi erdők fenntartása. - In: Kozák, L. (szerk.): Természetvédelmi élöhelykezelés. Mezőgazda Kiadó, Budapest, pp. 195-198.

Bozó, L. (2015): Kevermes és a lőkösházi Turai-gyep madárvilága. - A Puszta 24: 225-250.

Bozó, L. (2014): Kevermes természeti értékei napjainkban. - Kézirat, Kevermes, 49 p.

Bozó, L. (2012): Kevermes madárvilága. - Dél-békési Természetvédelmi és Madártani Egyesület, Kevermes, $144 \mathrm{p}$.

Gál, J. (1968): A mezővédő erdősávok növényvédelmi vonatkozásai. - Erdészeti Lapok 103: 450476.

Gál, J. \& Marosán, M. (2003): A mezőgazdasági tevékenység által okozott kár a vadállományban. Növényvédelmi tanácsok: kertészet, növénytermesztés, szaktanácsadás 12: 36-37.

Halász, A., Tasi, J., \& Rásó, J. (2015): Fás legelők, legelőerdők, erdősávok és fasorok használata ökológiai gazdálkodási rendszerben. Növénytermelés 64: 77-89.

Haraszthy, L. (szerk.) (1998): Magyarország madarai. - Mezőgazda Kiadó, Budapest, 441 p.

Herrmann, G. \& Plakolm, A. (1991): Ökologische Landbau. - Österreichischer Agrarverlag, Wien, $158 \mathrm{p}$.

Horváth, M. (2009): Habitat - and Prey - of selection of Imperial Eagles (Aquila heliaca). - Phd thesis. ELTE TTK, Budapest, 119 p.

Kromp, B. (1998): Wiener Windschutzhecken. - Magistrat der Stadt Wien, Wien, 19 p. 
Legány, A. (1991): A mezővédő erdősávok és fasorok madártani szerepe és természetvédelmi jelentősége. - Aquila 98: 169-180.

Marton, A. \& Csikós, Cs. (2004): Mezővédő erdősávok és a fenntartható fejlődés. - Környezeti Tanácsok 4. Kiadja: KÖTHÁLÓ, Környezeti Tanácsadó Irodák Hálózata, közreműködő: CSEMETE Természet- és Környezetvédelmi Egyesület, Szeged.

MME Nomenclator Bizottság (2008): Magyarország madarainak névjegyzéke. Nomenclator Avium Hungariae. An annotated list of the birds of Hungary. - Magyar Madártani és Természetvédelmi Egyesület, Budapest, 278 p.

Princé, K., Jiguet, F. (2013): Ecological effectiveness of French grassland agri-environment schemes for farmland bird communities. - J. Environ. Manage. 121: 110-116. doi: http//dx.doi. org/10.1016/j.jenvman.2013.02.039

Rakonczay, Z. (1992): Az alföldi erdők szerepe a természetvédelemben; Az Alföld-fásítás aktuális kérdései. - Tudományos emlékülés Kaán Károly születésének 125. évfordulója alkalmából. Konferenciakiadvány, Püspökladány pp. 59-62.

Szarvas, P. (2010): Mezővédő erdősávok, fasorok jellemzése, ökológiai feltárása, kihatásai. Értekezés a doktori (Ph.D.) fokozat megszerzése érdekében a Növénytermesztési- és Kertészeti Tudományok, Élelmiszertudományok tudományágban. Debrecen, 198 p.

Széles, Zs. E. (2010): Kék vércse gyülekezökori élöhelyhasználatának és táplálékösszetételének elemzése a Dél-Hevesi Régióban. - Diplomamunka, Debrecen, 47 p.

Szép, T. (2007): Madarak monitorozása: ökológiai és evolúciós folyamatok feltárásának lehetőségei. - Doktori disszertáció, Nyíregyháza, 150 p.

Takács, V. (2008): Útfásítások közlekedésbiztonsági vizsgálata a Sopron-Fertöd kistérség területén. - Doktori disszertáció, NyME, Sopron, 153 p.

Vahid, Y. \& Vahidné Kóbori, J. (2005): Erdőfejlesztési politikánk múltja és jelene. - Agrárágazat 6: 94-96.

Wretenberg, J., Pärt, T. \& Berg, Å. (2010): Changes in local species richness of farmland birds in relation to land-use changes and landscape structure. - Biol. Conserv. 143: 375-381. doi: http:// dx.doi.org/10.1016/j.biocon.2009.11.001

\section{Internetes hivatkozások:}

http1: www.maps.google.hu

http2: www.nebih.gov.hu/szakteruletek/szakteruletek/erdeszeti igazgatosag/aktualitas/ketmilliohektar.html

http3: www.vassarstats.net 


\title{
Songbird migration in a channel-sided alley
}

\author{
László Bozó ${ }^{1}$, Erna Bozóné Borbáth ${ }^{1}$ and Levente Tar $^{2}$ \\ ${ }^{1}$ H-5744 Kevermes, Battonyai utca 10, Hungary \\ ${ }^{2}$ H-5600 Békéscsaba, Zsíros u. 10. fsz. 5, Hungary \\ e-mail: bozolaszlo91@gmail.com
}

We studied the songbird migration in a channel-sided alley in Southeast Hungary, Kevermes in the autumn of 2016 with the methods of bird ringing. Near the channel we also ringed birds in an oleaster forest (which is rich in succulent plants) and compared the number of birds migrating through in both habiats. The study revealed, that the channel is crucial for most songbird species during migration, however, species that spent more time in the area used primary the forest with more food. Additionally, some species changed its breeding habitats (forests) and in autumn occured mostly in the channel. For these reasons, it would be appropriate for nature conservation to protect these habitats, or at least reduce the current habitat destructions.

Keywords: songbird migration, channel, alley, bird ringing, habitat destruction 